\title{
Sciendo
}

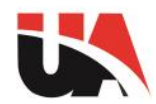

\section{SCAPEGOATING IN 'THE STRANGER’ BY ALBERT CAMUS}

Diana-Eugenia PANAIT-IONCICĂ ${ }^{1 *}$

Received: February 2021 | Accepted: February 2021 | Published: April 2021

Please cite this paper as: Panait-loncica, D.E. (2021) Scapegoating in 'The stranger' by Albert

Camus, Holistica Journal of Business and Public Administration, Vol.12, Iss.1, pp.89-96

\begin{abstract}
The present paper intends to discuss the amount to which scapegoating (as understood by René Girard in 'The Scapegoat') can be applied to Camus's novel 'The Stranger'. While issues arise when we are trying to apply Girard's definition of scapegoating to the famous novel by Camus, this paper shall try to prove that they are only apparent issues, and that the novel is a perfect illustration of Girard's theory.

Keywords: scapegoating, literature, contemporary novel
\end{abstract}

\section{Introduction}

The present paper intends to discuss the amount to which scapegoating (as understood by René Girard in 'The Scapegoat') can be applied to Camus's novel 'The Stranger', published in 1968.

In Girard's view, scapegoating 'describes simultaneously the innocence of the victims, the collective polarizing against them, and the collective finality of the respective polarizing.' (Girard, 2000, p.47)

There are several problems that appear when trying to apply this definition to 'The Stranger'. We shall try to prove that they are only apparent problems.

In the first place, the most obvious question set before us is 'Is this really a case of scapegoating?' The victim does not appear to be innocent: Mersault has actually committed the crime he is accused of: he shot, with five bullets, and for no apparent reason, a man who had not directly harmed him in any way. The murder of the Arab is explicitly described in the book, and never questioned.

Moreover, Mersault is judged legally, in a court of law - which appears to raise the question of whether this is an instant of collective violence, or simply justice.

\footnotetext{
${ }^{1}$ Bucharest University of Economic Studies, Bucharest, Romania, diana_ioncica@yahoo.com.

* Corresponding author.
} 


\section{Scapegoating in Camus's novel}

We shall try to address, to begin with, the first problem: the guilt of the victim. This case is actually discussed by Girard, in 'The Scapegoat'. He says:

'Let us take, for example, another convict. He has effectively committed the crime... Collective violence loses its arbitrary character (in the most obvious sense of the word). It sanctions the act it pretends to sanction. In these circumstances, one could imagine that there are no persecutory distortions... In reality, they exist... The vision of the persecutors remains irrational, as it inverses the relation between the global situation of society and individual transgression. If between the two levels there is a causal link... it can only go from the collective to the individual. The persecutory mentality moves in the opposite direction. Instead of seeing in the individual microcosm the reflex or the imitation of the global level, it seeks in the individual the origin and cause of everything that harms it. Real or not, the responsibility of the victims suffers the same fantastic expansion.' (Girard, 2000, p. 29. My translation)

In order to fully explain the problem of guilt - which lies at the core of the novel - an additional question must be asked - and, hopefully, answered. The question is 'what crime is Mersault actually trialed for?', and the answer is, paradoxically, far from the one we would expect. For, indeed, Mersault is not actually condemned for the killing of the Arab. This is how Camus summarizes the subject of 'The Stranger': 'In our society, any man who does not cry at his mother's funeral, risks to be condemned to death.' (Camus, Preface to 'The Stranger', 1968, p. 19. My translation) The reason for Mersault's - the stranger's - condemnation is not, consequently, to be sought in his crime. It should be sought in the very thing - defining his personality - that makes him a stranger.

So why is Mersault - an apparently common man, a clerk caught in the routine of daily existence - considered to be a stranger, and a menace to society? What are his defining features?

According to Camus, his essential features are 'total honesty' and 'negativity'. In the course of the book, Mersault resumes himself to answering questions. 'Thus, I define my character negatively', Camus says. 'He has no initiative; his answers are negative, too, being part of 'a kind of difficult march towards a holiness of negation.' (Camus, Preface to 'The Stranger', 1968, p. 20. My translation)

As far as honesty is concerned, Camus gives the following explanation:

'To lie does not only mean to tell what is not there. It also means to tell more than there is, and, as regards the human soul, to tell more than you feel. It is what we all do, all day long, to simplify our lives. Mersault, although he does not seem to, does not want to simplify his life. He tells what he is, refuses to hide his feelings, and, immediately, society feels threatened. He is asked to say he regrets his crime, following the established formula. He says he feels in this respect more boredom than real regret. This is the nuance that condemns him.' (Camus, Preface to 'The Stranger', 1968, p. 21. My translation) 
Here is how this is expressed in the novel. When Mersault is first interrogated by the examining magistrate, and fails to reveal any feeling when shown the crucifix and prompted to ask God's forgiveness, the magistrate 'seemed very tired... He said: "I have never seen somebody as hardhearted as you. The criminals who came before me have all wept when seeing this image of pain [the crucifix]"... He asked me...if I regretted my act. I thought about it and said I did not feel any real remorse, just a kind of boredom.' (Camus, The Stranger, 1968, p. 57. My translation)

Regarding the question whether the novel depicts a genuine instance of collective violence, or a plain legal case, it would be helpful to resort once again to Girard's assertions.

In his study, Girard refers to 'collective persecutions or to persecutions having a collective resonance.' By 'collective persecutions' he understands 'violence committed directly by murderous crowds.' By 'persecutions having a collective resonance' he understands 'violence, legal in form, but encouraged by an excited public opinion. This kind of persecutions appear in times of crisis that favour the formation of mobs.' (Girard, 2000, p. 19. My translation)

In 'The Stranger' we would find, then, an instance of 'persecution having a collective resonance'. Several objections could be brought to this assertion. In the first place, the amount to which the persecution is 'collective', i.e., it involves the society as a whole and not just a particular individual. Mersault, more than anybody else, could be viewed as a special case, a unique personality following his solitary path.

Secondly, the state of 'crisis' society is in is not apparent. Life, in the novel, seems to be extremely monotonous, fixed and settled.

The first objection finds its final answer in the end of the book - which reveals the connections between the stranger's destiny and those of his judges. It would be useful to mention, at this point, an important characteristic of the 'stranger' Camus reveals. He is one of those 'beings without lie, therefore unreal. They do not belong to the world. Undoubtedly, I am not a novelist in the strict sense of the word. Rather, an artist who creates myths to give the full measure of his passion and anxiety. And that is why the beings that thrilled me in this world were always those with the force and exclusiveness of myths.' (Camus, Preface to 'The Stranger'1968, p. 12. My translation)

It is in this sense that Camus sees his character as 'the only Christ we deserve.' Mersault does have the 'force and exclusiveness' of a myth, and his force comes from his ability to rebel.

'Apparently negative, as it does not create anything, revolt is profoundly positive, as it reveals in man what he always has to defend.' (Camus, The Revolted Man, 1994, p. 224. My translation)

Coming back to Girard's argumentation, that is, to the stereotypes of persecution, we should note that 'whatever their real causes may be, the crises triggering collective persecutions are always felt alike by those who live them. The most powerful impression 
is invariably that of the complete destruction of the social, of the end of norms and differences defining cultural rules...

...When the society is in a crisis situation... a 'faster' reciprocity is established, not only on the level of positive exchanges... but also on the level of hostile or 'negative' trades. Reciprocity, visible through immediacy, is not one of good but of vicious behavior (insults, revenge, neurotic symptoms). Though it places people in opposition, this negative reciprocity levels out comportment, triggering a predominance of 'the same' [du même] always slightly paradoxical.' (Girard, The Scapegoat, 2000, pp. 20-21. My translation)

This kind of behavior is the one that can be observed during Mersault's trial. When finishing the pleading, the prosecutor gave him 'such a triumphant look that, for the first time in years, [he] felt the ridiculous need to cry because [he] realized how much all these people hated [him].' (Camus, 1968, The Stranger, p. 73)

The difference between the crime he has actually committed and the one he is accused of is immense. It obeys the rule Camus put forward 'You are never convicted for the crime you thought you committed.' The prosecutor's words are significant in this respect.

'Yes, I accuse this man of burying his mother with the soul of a criminal.' 'The lack of soul, as it is revealed in this man, is an abyss in which society might fall.'(Camus, 1968, The Stranger, pp. 78, 82)

They hardly even take into consideration the actual crime. What he is really accused of is the inability to conform to the conventions of society. This is typical for the persecutory mentality. Girard's arguments suit the situation perfectly.

'Any individual manifesting difficulties in adjusting to the collectivity - the stranger, the orphan, the poor or, simply, the newcomer - is interchangeable with the infirm...

Irrespective of the domain it pertains to, abnormality may serve as a criterion in the selection of victims...

All extreme features attract collective anger...

There is such thing as social abnormality; here, the average defines the norm. The further you get from the most common social status, one way or another, the risks of persecution increase.' (Girard, 2000, pp. 26-27)

What the novel develops, then, is 'the theme of the stranger banned or assassinated by collectivity' - a mythical theme, as described by Girard. As in all cases of scapegoating, 'persecutors always end up by convincing themselves that ... a single individual may become extremely harmful for society, despite his relative lack of power... For a criminal, even a diabolical one, to bring a whole community to undifferentiation, he has to strike its vital centers, committing such crimes as parricide, incest, a.s.o.'

If the criminal happens to commit another crime, while carrying the marks of the scapegoat, the imagination of the persecutors will make the necessary corrections. 
'The mob always has the tendency to persecute... It seeks, by definition, to act, but, as it cannot act on the natural causes, it looks for accessible causes that would appease its appetite for violence...

Mobilization can only be military or partisan, i.e., against an already designated - or soon to be designated - enemy...

The crimes the victims are accused of may be real, but, even in this case, they do not play the decisive role in the choice the persecutors make; the victim's belonging to certain categories exposed to persecution plays the most important role.' (Girard, 2000, pp. 2325. My translation)

As the above quoted fragments confirm, the crime of the victim of persecution can be extended to suit the accusation and, thus, to justify the sacrifice. This is what happens in the novel we discuss. Let us compare the actual description of the crime - narrated from the criminal's point of view - with the accusations uttered during the trial.

'It was the same sun from the day when I had buried my mother and, like then, my forehead, especially, ached and all the veins underneath throbbed. Because of the unbearable burn, I moved forward... Then everything shook. The sea exhaled a hot, dense breath. The sky seemed to open up to release a shower of fire. All my being was strained and my hand was clutching the revolver. The trigger moved... and there, in the deafening noise it all began... I understood I had broken the peace of the day, the extraordinary silence of a beach where I had been happy. Then I fired four more bullets into the inert body, in which they sunk, unseen. It was like knocking four times at the gate of disaster.' (Camus, 1968, The Stranger, pp. 49-50)

Seen from the inside, the crime has no plausible explanation. It is utterly absurd, pointless. A game of hazard. An outside view will change things radically. It would be interesting to quote, in this respect, Camus's observation:

'Looking at these lives from the outside, they are attributed a coherence and a unity they cannot really have, but which seem obvious for the observer. He only sees the outline of these lives, without seeing the detail that gnaws at them. We superimpose art on these existences. Basically, we fictionalize them.' (Camus, Preface to 'The Stranger', 1968, p. 19. My translation)

The same idea is expressed by Sartre, when saying: 'To turn the most trivial event into an adventure, all you have to do is to narrate it.' (Jean Paul Sartre, La Nauseé, 1938, p. 58. My translation)

The prosecutor's version of the events operates such a 'fictionalizing', not only in the sense that it introduces in the structure of the events a coherence they would not otherwise have, by assuming the crime was premeditated (he does not alter any of the events preceding the Arab's death, he only connects them, adding intentionality to the existent facts), but also in a more insidious manner. 
He says: < 'This court, gentlemen, will judge tomorrow the most abominable crime: a parricide'...The horror this crime inspired him faded in front of the horror he felt seeing my callousness... 'I'll say the man sitting in front of you is also guilty of the crime this court will have to judge tomorrow. He must be punished accordingly... On this human face I read nothing but monstrosity.'> (Camus, 1968, The Stranger, p. 83)

We can see here the way the persecutory mentality works. It invents the crimes it does not find. Since the stranger's crime was not a 'fundamental crime' - in Girard's definition, 'a crime attacking the bases of the cultural order, family differences... without which social order would not be possible' - the persecutors turn it into a fundamental crime. (Girard, 200, p. 23)

The object of the trial is Mersault's insensitive attitude towards his mother, his placing her in an asylum, the lack of tears at her funeral, and finally his statement that he had not suffered when she had died. This attitude is grotesquely transformed and he is attributed the responsibility not only for his mother's death, but for all the deaths society had no way of dealing with. He is blamed, in other words, however absurd this may sound, for the very fact that we are mortal.

It is at this point that we can best understand the function of scapegoating in the story. And, not incidentally, it is at this point that the character starts to transform, starts, actually, to reveal himself - acquires a voice.

Up to this point, the situation in the trial was best summed up by the lawyer who said, 'Here is the very image of this trial. Everything is true and nothing is true.' (Camus, 1968, The Stranger, p. 74) The same lawyer makes him realize his situation : 'I thought that in this way [ by saying 'I committed the crime' instead of 'He committed the crime' ] he pushed me even further from my act, he reduced me to nothing and, in a way, he replaced me.' (Camus, 1968, The Stranger, p. 84)

He comes to think that 'the only thing that mattered was a possibility of escape, a way out of the implacable ritual, an irrational attempt that would leave room for hope... It is essential to give the convicted man a chance... At this moment, all I cared for was to escape the mechanism, to know if the unavoidable had a way out.' (Camus, 1968, The Stranger, pp. 88, 90, 87. My highlighting)

It is, in Girard's terms, the moment when the victim raises his voice to cover the voices of the persecutors heard 'since the foundation of the world'. It is the beginning of the destruction of the myth.

The confrontation with the priest may be said to follow this line of demythization. When the priest says 'I'll pray for you', the revolt Mersault feels finally acquires expression.

'Then, I don't know why, something snapped inside me... I started yelling with all my strength and told him not to pray... None of his certitudes was worth a hair on a woman's head. He wasn't even sure to be alive, as he lived like a dead man. I seemed to have nothing. But I was sure of myself, sure of everything, surer than he was, sure of my life and my oncoming death... It was like I had been waiting all this time for this moment and 
for this dawn when I would have to pay. Nothing, nothing mattered and I knew well why. He knew it too... What importance did it have, for me, the death of the others, a mother's love, the priest's God, the lives we choose, the destinies we choose, when there is a single destiny that must choose me and, along with me, billions of privileged men, who, like himself, considered themselves my brothers. Did he understand? Everybody was privileged. There was nothing but privileged people. The others, too, shall be convicted one day. He'll be convicted. What did it matter if, having been accused of murder, he would be executed because he hadn't cried at his mother's funeral? ... Did he understand this condemned man?' (Camus, 1968, pp. 97-98)

This fragment offers the explanation for the question we asked earlier in the essay namely, what makes the stranger's destiny have a collective importance, why is it not a singular path, irrelevant for the lives of the others? The answer his words offer is: because we are all 'condemned', we are all 'strangers', in possession of a truth we do not want to acknowledge as ours. The man uttering this frightening truth must consequently be killed (as he becomes responsible for the truth he reveals). He is, indeed, 'the only Christ we deserve.

\section{Conclusions}

'The marks of the selection of victims do not refer to the difference existing inside the system, but to the difference outside the system, to its possibility of differing from its own difference, in other words, to stop differing at all, to cease existing as a system...

Infirmity confuses the differences around it, making them monstrous, making them clash and mix and finally disappear. The difference outside the system frightens, as it suggests the truth of the respective system, its relativity, its fragility and mortality...

The strangers are incapable of respecting the 'true' differences; they have no morals or no taste; they grasp incorrectly the differential...

It is not the difference that obsesses the persecutors, but its unspeakable opposite: the undifferentiation...

The vocabulary of prejudice...does not express the hatred towards difference, but towards the loss of difference. We do not see in the other another nomos, but the anomaly; the infirm becomes deformed; the stranger becomes homeless.' (Girard, 2000, pp.30-31)

The above quoted fragments may be read, in our opinion, as a summary of 'The Stranger'. What makes Mersault a scapegoat (or a stranger, in this case the terms are synonymous) is his irreverence towards the differences of society, encoded in its conventions. He attracts the hatred of his fellow-men by refusing to hide the truth of the system, and of each of its components - mortality. He refuses to accept the limit, so he has to pay the price of freedom. 
HOLISTICA Vol 12, Issue 1, 2021, pp.89-96

'For the first time, in a long time, I thought of my mother... So close to dying, my mother must have felt liberated and ready to live everything from the beginning. Nobody, nobody had the right to cry for her. I, in my turn, felt ready to relive everything. As if this fury had purged me of all evil, had drained me of hope, in front of this night heavy with signs and stars, I was opening up for the first time to the tender indifference of the world. I felt it so alike myself, so brotherly at last, that I realized I had been happy, and was happy still. For everything to be over, and so as to feel less alone, all I had left to desire was to have, on the day of my execution, a crowd of on-lookers to meet me with cries of hatred.' (Camus, 1968, The Stranger, pp. 99-100)

This is, in Camus's words, 'the story of a man who, without any heroic attitude, accepts to die for the truth.' It is a negative truth, 'the truth of feeling and being, without which no conquest on ourselves or the world will ever be possible.' (Camus, 1968, The Stranger, p. 11) The destruction of the myth ends up in myth.

\section{References}

Camus, Albert (1968). The Stranger. Bucharest: Editura pentru literatură.

Camus, Albert (1994). The Revolted Man. Bucharest: RAO International Publishing Company.

Girard, René (2000). The Scapegoat. Bucharest: Nemira.

Sartre, Jean Paul (1938). La Nauseé. Paris: Gallimard. 